\title{
Invitro Bioefficacy of $\boldsymbol{B}$. subtilis Isolates against Ralstonia solanacearum Causing Bacterial Wilt of Brinjal
}

\author{
Supriya $^{1}$, S. T. Yenjerappa ${ }^{1}$, S. C. Sreedevi ${ }^{1}$ and Mahadevaswamy ${ }^{2}$ \\ ${ }^{1}$ Department of Plant Pathology, University of Agricultural Sciences, Raichur, India \\ ${ }^{2}$ Department of Agricultural microbiology, University of Agricultural Sciences, \\ Raichur- -584100, India \\ *Corresponding author
}

Keywords

B. subtilis,

Ralstonia

solanacearum, zone of inhibition and rhizobacteria

Article Info

Accepted:

22 June 2020

Available Online:

10 July 2020

\section{A B S T R A C T}

Bacterial wilt caused by Ralstonia solanacearum, a genetically diverse soil-borne pathogen with a wide host range, is a devastating plant vascular disease (Hayward, 1991). No effective chemical product is available for Ralstonia-induced wilt. Alternative methods such as biological control agents (BCAs) have shown effectiveness. Bacillus subtilis is a non-pathogenic bacterium that lives in soil, often in association with roots of higher plants and it also produces a variety of biologically active compounds with a broad spectrum of activities towards phytopathogens and that are able to induce host systemic resistance. Thirty Bacillus subtilis isolates were isolated from rhizospheric soil of healthy brinjal plants from Hyderabad Karnataka region. These isolates were evaluated by screening their antagonistic ability to reduce incidence of bacterial wilt of brinjal caused by Ralstonia solanacearum in vitro. All the isolates showed the varied level of inhibition of Ralstonia solanacearum. Among different isolates, BS6 showed highest inhibition zone of $19.5 \mathrm{~mm}$ diameter followed by BS-10 showed $18.16 \mathrm{~mm}$ and least zone of inhibition was produced by an isolate BS-11 of 5.5 mm diameter.

\section{Introduction}

Soil has enormous potential of antagonistic microorganisms, which are beneficial in reducing the pathogen population through different modes of action. Certain bacterial species associated with or livings in the rhizosphere improve the plant growth and were termed as plant growth-promoting rhizobacteria (PGPR) by Kloepper et al., (1980). Among the PGPR microbes, $B$. subtilis is the one which plays a major role in plant growth promotion (Glick, 1995) and biocontrol of plant pathogens. Bacillus subtilis is a gram positive, rod shaped having peritrichous flagella (Nakano and Hulett, 1997). The colony morphology of the isolates exhibit a range from flat to filamentous or 
branching (Wafula et al., 2014), having either smooth or rough colony with colour ranging from white to cream. They grow well at $\mathrm{pH}$ ranging from $5-6.5$ and the temperature between 25 to $35{ }^{\circ} \mathrm{C}$ commonly associated with soil. It is an endospore forming bacteria (Piggot and Hilbert, 2004) which support to withstand extreme temperatures as well as dry environments. This endospore helps the organism to persist in the environment until conditions become favorable (Wafula et al., 2014). Bacillus subtilis (Cohn, 1872), is an adept rhizobacterium and has gained global attention as a biopesticide (Edgecomb and Manker, 2006) for the control of several plant diseases. One of the major factors limiting the cultivation of brinjal crop is the incidence of bacterial wilt caused by Ralstonia solanacearum. The soil-borne pathogen causes substantial economic loss to the crops.

Bacterial wilt of brinjal and other solanaceous vegetables caused by Ralstonia solanacearum (Smith) Yabuchi et al., (1995) is a devastating disease of crops (Hayward, 1991). It occurs widely in tropical and subtropical regions of the world (Kelman, 1998) causing severe losses in yield. The disease affects crops such as tomato, eggplant, potato, tobacco and pepper as well as other important crops like banana, peanut and ginger

Ralstonia solanacearum is an aerobic nonsporeforming, rod shaped, non-capsulated, Gram-negative, plant pathogenic bacterium. The organism is motile with tuft of polar flagella. It colonises the xylem tissues, causing bacterial wilt in wide range of potential crop plants. Bacterial wilt of tomato, pepper, eggplant and Irish potato diseases, first time proved to be invaded by Erwin Frank Smith. They appeared dull white with light pink colored center on TZC medium and the colonies were highly fluidal producing copious slime. The bacterium was positive for nitrate reduction test and negative for starch hydrolysis and gelatin liquification. Because of its devastating lethality, $R$. solanacearum is now more intensively studied phytopathogenic bacterium and bacterial wilt of tomato is a model system for investigating the mechanisms of pathogenesis. Ralstonia is synonymous to Pseudomonas with a similarity in most of the aspects except, it does not produce fluorescent pigment. It belongs to the Kingdom: Bacteria; Phylum: Proteobacteria; Class: Beta-Proteobacteria Order: Burkholderiales; Family: Burkholderiaceae and Genus: Ralstonia. With this background information, the present investigation was undertaken to study the in vitro bioefficacy of $B$. subtilis isolates against Ralstonia solanacearum causing bacterial wilt of brinjal

\section{Materials and Methods}

\section{Collection and isolation of $B$. subtilis isolates}

The Bacillus subtilis were isolated from the soil sample collected during survey from rhizosphere of brinjal from five different districts viz., Raichur, Kalburgi, Yadgir, Bidar, Koppal of Hyderabad Karnataka region. Isolation of Bacillus subtilis was carried out by serial dilution and plate count technique on nutrient agar medium and isolates obtained were designated as BS-1 to BS-30. Thereafter In vitro experiments to assess antagonistic effect of $B$. subtilis isolates against Ralstonia solanacearum were also conducted.

\section{Bioefficacy of $B$. subtilis isolates against Ralstonia solanacearum}

The thirty isolates of $B$. subtilis were evaluated for their ability to inhibit the growth of $R$. solanacearum by following the dual culture assay (Ganesan and Gnanamanickum, 1987). A luxuriant lawn of $R$. solanacearum 
was prepared on nutrient agar plates by spreading $1000 \mu \mathrm{l}$ of 24hrs old $R$. solanacearum multiplied in nutrient broth. Ten $\mu l$ of each isolate of B. subtilis grown in nutrient broth overnight was spotted on to the lawn of pathogen. The inoculated plates were incubated at $30{ }^{\circ} \mathrm{C}$ for 48 hours. Three replications were maintained for each treatment. Observations were recorded for the zone of inhibition produced by an antagonist around the growth of the pathogen. Control was maintained without inoculating antagonist.

\section{Results and Discussion}

Each of the thirty Bacillus subtilis isolates were tested for inhibition of $R$. solanacearum by dual culture technique on nutrient agar medium. The isolates exhibited great variation in inhibition of the pathogen, ranging from $5.5 \mathrm{~mm}$ to $19.5 \mathrm{~mm}$ diameter. The isolate BS-6 produced the highest inhibition zone of $19.5 \mathrm{~mm}$ diameter, which significantly inhibited the pathogen and that was followed by BS-10 (18.16 mm), BS-3 (17.83 mm), BS-4 (17.16 mm), BS-29 (17.16 $\mathrm{mm})$, BS-26 (17.16 $\mathrm{mm})$ and BS-15 (16.00 $\mathrm{mm}$ ) and least zone of inhibition was produced by an isolate BS-11 of $5.5 \mathrm{~mm}$ diameter. Out of $30 \mathrm{~B}$. subtilis isolates tested, 8 isolates produced a zone of inhibition of $\geq 15 \mathrm{~mm}$ diameter. Furthermore, remaining 22 isolates indicated a zone of inhibition of $<15$ $\mathrm{mm}$ diameter (Table 1). There was a significant difference in the formation of inhibition zone by the isolates of B. subtilis against $R$. solanacearum (Plate 1). Further, irrespective of isolates, $48 \mathrm{~h}$ old culture of $B$. subtilis produced more zone of inhibition than $24 \mathrm{~h}$ old culture probably due to the secretion of ample quantity of antibiotics due to the prolonged incubation. Growth inhibition of pathogen may be due to the secondary metabolites specially the antibiotics secreted by the bacterial biocontrol agents on the agar media, which have broad spectrum activity (Fig. 1).

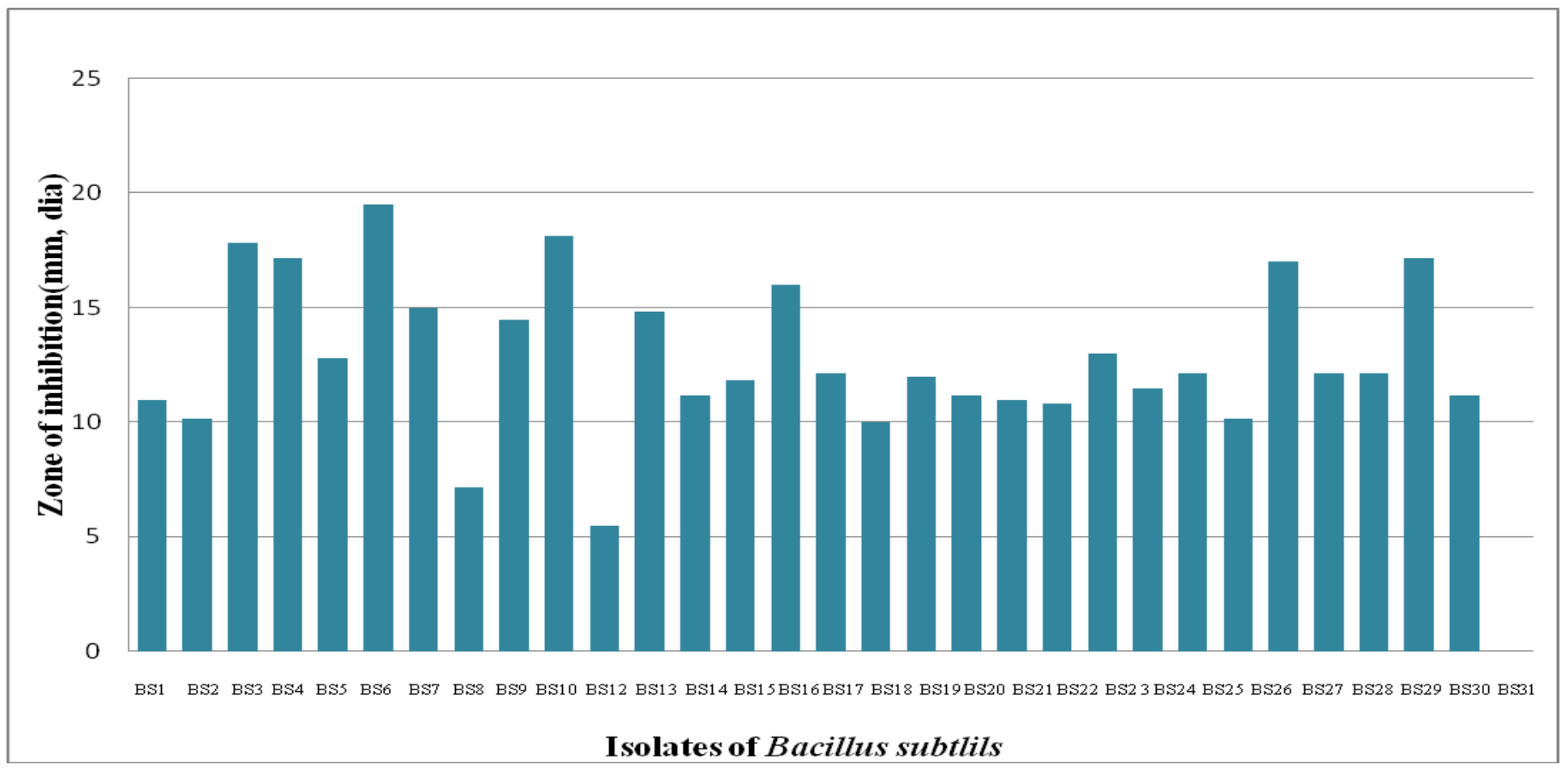

Plate.1 Invitro bioefficacy of B. subtilis isolates against Ralstonia solanacearum 

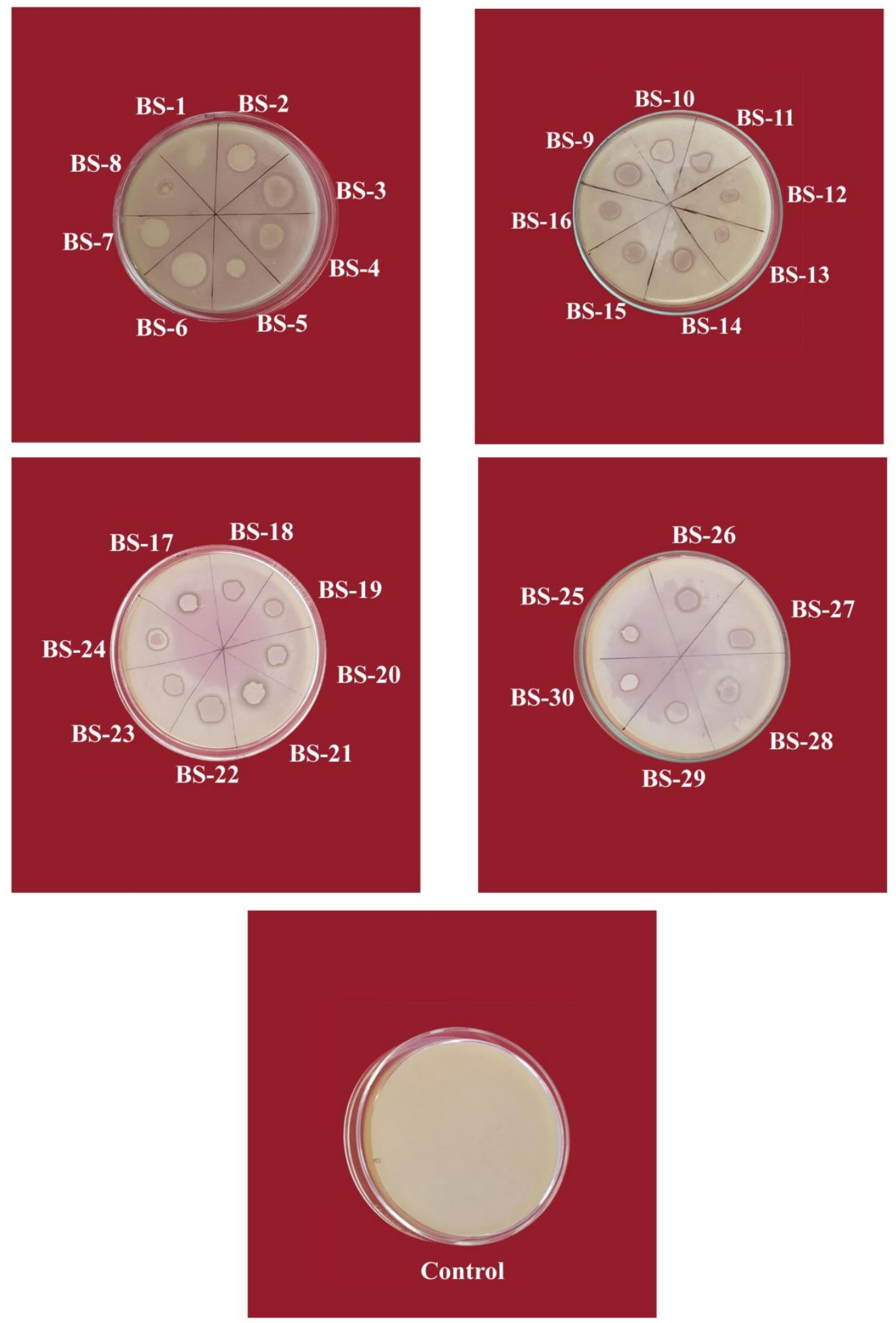

Fig.1 Invitro bioefficacy of B. subtilis isolates against Ralstonia solanacearum 
Table.1 Invitro bioefficacy of $B$. subtilis isolates against Ralstonia solanacearum

\begin{tabular}{|c|c|c|}
\hline Sl. No. & B. subtilis Isolates & Zone of inhibition ( $\mathrm{mm}$, dia) \\
\hline 1 & BS-1 & 11.00 \\
\hline 2 & BS-2 & 10.16 \\
\hline 3 & BS-3 & 17.83 \\
\hline 4 & BS-4 & 17.16 \\
\hline 5 & BS-5 & 12.83 \\
\hline 6 & BS-6 & 19.50 \\
\hline 7 & BS-7 & 15.00 \\
\hline 8 & BS-8 & 07.16 \\
\hline 9 & BS-9 & 14.50 \\
\hline 10 & BS-10 & 18.16 \\
\hline 11 & BS-11 & 05.50 \\
\hline 12 & BS-12 & 14.83 \\
\hline 13 & BS-13 & 11.16 \\
\hline 14 & BS-14 & 11.83 \\
\hline 15 & BS-15 & 16.00 \\
\hline 16 & BS-16 & 12.16 \\
\hline 17 & BS-17 & 10.00 \\
\hline 18 & BS-18 & 12.00 \\
\hline 19 & BS-19 & 11.16 \\
\hline 20 & BS-20 & 11.00 \\
\hline 21 & BS-21 & 10.83 \\
\hline 22 & BS-22 & 13.00 \\
\hline 23 & BS-23 & 11.50 \\
\hline 24 & BS-24 & 12.16 \\
\hline 25 & BS-25 & 10.16 \\
\hline 26 & BS-26 & 17.00 \\
\hline 27 & BS-27 & 12.16 \\
\hline 28 & BS-28 & 12.16 \\
\hline 29 & BS-29 & 17.16 \\
\hline 30 & BS-30 & 11.16 \\
\hline 31 & Control & 00.00 \\
\hline S.Em \pm & - & 0.48 \\
\hline C.D at $1 \%$ & - & 1.82 \\
\hline
\end{tabular}

Chen et al., (2013) screened 60 strains of $B$. subtilis obtained from the rhizosphere soil of tomato at various locations across China against $R$. solanacearum (bacterial wilt of tomato) Of these, six strains exhibited 50 per cent inhibition of radial growth of $R$. solanacearum under in vitro conditions. Antagonistic activity of $P$. fluorescens, $P$. putida, B. subtilis and Enterobacter aerogenes both by in vitro and in vivo 
conditions against $R$. solanacearum was performed by Seleim et al., (2011) and they reported the highest bacterial wilt reduction by $P$. putida followed by $B$. subtilis. Basha et al., (2017), tested the antagonistic efficiency of bacterium $P$. fluorescens, $P$. aeroginosa, $B$. subtilis and $B$. megatherium against $R$. solanacearum causing bacterial wilt of tomato by in vitro and found that B. subtilis was most effective in inhibiting the growth of the pathogen followed by $P$. fluorescens, $B$. megatherium and $P$. aeroginosa were found to be least effective.

In conclusion, $B$. subtilis exhibited sufficient antibiosis capability due to its good inhibitory performance against Ralstonia solanacearum. B. subtilis strains with good antimicrobial properties have been used as an alternative to chemical pesticides in disease management strategy and should be further studied under field condition and possibly scaled-up for the control of numerous diseases and great yield losses.

\section{References}

Basha, J. C. R., Manjula, C. P. and Prasanna Kumar, M. K., 2017, Management of bacterial wilt of tomato caused by Ralstonia solanacearum by bacterial antagonists and botanicals. Int. J. Pl. Sci., 12(2): 114-119.

Chen, M., L., Gou, G. H., Hong, X. L. and Jian, H. G., 2013, Analysis of defence enzymes induced by antagonistic bacterium Bacillus subtilis strain AR12 towards $R$. solanacearum in tomato. Annu. Microbiol., 58(4) 573-578.

Cohn, F., 1872, Untersuchungenuber Bacterien. Beitrage zur Biologie der Pflanzen, pp. 127-224.

Edgecomb, D. W. and Manker, D., 2006, Bacillus subtilis strain QST 713, bacterial disease control in fruit, vegetable and ornamental production.
Biologische Bundesanstalt für Landund Forstwirtschaft., pp.167-169.

Ganeshan and Gnanamanickum., 1987, Biological in control of Sclerotium rolfsii sacc. peanut by inoculation with Pseudomonas fluorescens. Soil Biol. Biochem., 19(1): 32-38.

Glick, B. R., 1995, The enhancement of plant growth promotion by free-living bacteria. Can. J. Microbiol., 41: 9-17.

Hayward, A.C., 1991, Biology and epidemiology of bacterial wilt caused by Pseudomonas solanacearum. Ann. Rev. Phytopathol., 29: 65-87.

Kloepper, J. W., Schroth, M. N. and Miller, T. D., 1980, Effects of rhizosphere colonization by plant growth-promoting rhizobacteria on potato plant development and yield. Phytopathol., 70: 1078-82.

Kelman, A., 1998, One hundred and one years of research on bacterial wilt. In: Prior P, Allen C, Elphinstone J. (eds). Bacterial Wilt: Molecular and Ecological Aspects, pp.1-5. INRA Editions, Paris, France.

Nakano, M. and Hulett, M., 1997, Adaptation of Bacillus subtilis to oxygen limitation. FEMS Microbiol., 157(1): 1-7.

Piggot, P. and Hilbert, D. (2004). Sporulation of Bacillus subtilis. Current Opinion in Microbiol., 7( 6): 579-586.

Seleim, M. A. A., Saead, F. A., Abd-ElMoneem. K. M. H. and Abo-ELyousr, K. A. M., 2011, Biological control of bacterial wilt of tomato by plant growth promoting rhizobacteria. Plant Pathol J., 10(4): 146-153.

Wafula, E. N., Johnson, K., Daniel, K., Anne, M. and Romano, M., 2014, Isolation and characterization of Bacillus species from soil in Nigere tea catchment area of Murang'a county, Kenya. Int. J. Life Sci. Res., 2(3): 27-35.

Yabuchi, E., Kosako, Y., Yanno, I., Hotta, H. and Nishiuchi. Y., 1995, Transfer of 
two Burkholderia and an Alcaligenes species to Ralstonia genus nov: proposal of Ralstonia picketti (Ralstonia, palleroni and douderoff, 1973) comb. Nov. Ralstonia solanacearum (Smith 1896) comb. Nov. and Ralstonia eutropha (Davis 1969) comb. Nov. Microbio. Immune., 39:897-904.

\section{How to cite this article:}

Supriya, S. T. Yenjerappa, S. C. Sreedevi and Mahadevaswamy. 2020. Invitro Bioefficacy of $B$. subtilis Isolates against Ralstonia solanacearum Causing Bacterial Wilt of Brinjal. Int.J.Curr.Microbiol.App.Sci. 9(07): 3229-3235. doi: https://doi.org/10.20546/ijcmas.2020.907.376 